\title{
Institutional Quality and Economic Performance in Nigeria: A New Evidence
}

\author{
JONATHAN E. OGBUABOR \\ Department of Economics, University of Nigeria, Nsukka, NIGERIA \\ FIDELIA N. ONUIGBO \\ Department of Economics, Enugu State University of Science and Technology (ESUT), Enugu, \\ NIGERIA \\ ANTHONY ORJI \\ Department of Economics, University of Nigeria, Nsukka, NIGERIA \\ ONYINYE I. ANTHONY-ORJI \\ Department of Economics, University of Nigeria, Nsukka, NIGERIA
}

\begin{abstract}
Received: July 22, 2020. Revised: November 30, 2020. Accepted: December 3, 2020. Published: December 4, 2020.
\end{abstract}

\begin{abstract}
The question of whether institutional quality is an important driver of growth has been the subject of a growing literature in both developed and developing economies across the globe. This study revisits this relationship in Nigeria from 1981Q1 to $2016 Q 4$ and discusses the relevant policy implications for post Covid-19 Nigeria. The study adopted the ARDL approach which uses a bounds test approach based on unrestricted error correction model (UECM) to test for a long run relationship among the relevant variables. The findings indicate that institutional quality impacts negatively but insignificantly on growth in Nigeria, both at the aggregate and sectoral levels. However, initial output growth levels, capital and labour were found to be important drivers of growth in the country, while trade is growth-retarding. The study concludes that in this post Covid-19 era in Nigeria, there is need to improve the quality of socio-economic and political institutions in the country so that a more robust impact of these institutions can be felt in the economic performance of the country both at the aggregate and sectoral levels.
\end{abstract}

Key words: Institutional Quality; Economic Performance; ARDL Model; Nigeria

\section{INTRODUCTION}

The relationship between institutional quality and economic performance has been the subject of a growing literature in both developed and developing countries across the globe. This is because no economy exists in a vacuum. There are certain institutional factors that play important roles in the growth of every economy. For instance, lack of political rights (i.e. freedom to participate in the political process), lack of respect for the rule of law and civil liberties (such as the rights to free expression, to organize or demonstrate, and to freedom of religion, education, travel, and other individual rights), poor government regulations, and high level of corruption have been blamed for the economic stagnation in most developing countries (Siba, 2008). North (1991) defined institutions as the rule of the game in a society or more formally, the humanly devised constraints that shape human interaction. Benyah (2010) explained institutional quality as the extent to which procedures by regulatory authorities foster investor protection and enhance greater access to funds for borrowers. Dysfunctional institutions generally render the economic environment unproductive and obstruct trade, thereby encumbering the growth objective of an economy (Anyanwu \& Yaméogo, 2015)

Figure 1 (in appendix) reports the growth performance of the Nigerian economy. Panel A reports annual GDP growth while Panel B reports annual GDP per capita growth. Both panels aptly capture the poor performance of the Nigerian economy in recent years, especially the last recession of 2016 during which output plummeted and GDP per capita growth remained in the negative region. This raises concerns on the role of institutions in the Nigerian economic growth process. Thus, this paper examines the impact of 
institutional quality on economic performance in Nigeria. However, unlike the extant literature which is based on the traditional institutional variables documented in the World Governance Indicators such as control of corruption, government effectiveness, regulatory quality, rule of law, political stability and absence of violence/terrorism, and voice and accountability, this paper derives an institutional quality variable based on the data from Freedom House, which monitors political freedom in various countries across the globe on annual basis.

\section{AN OVERVIEW OF THE EMPIRICAL LITERATURE}

Following the initial studies by Mauro (1995) and Knack and Keefer (1995), a growing empirical literature on the role of institutions in driving growth has emerged. Some aspects of this emerging literature show that institutions play important roles in Africa's growth performance. For instance, in a study aimed at establishing the factors contributing to Africa's growth performance, Mijiyawa (2013) found that government effectiveness was one of the key drivers of growth over the period 1995-2005. Similar results were obtained by Anyanwu (2014) who found that government effectiveness was an important driver of growth in Africa during the period 1996 - 2010. Furthermore, both Anyanwu and Yaméogo (2015) and Mijiyawa (2015) document that political instability, which is a major component of institutional quality, hinders foreign direct investment inflows into Africa, and thus impedes growth. Chikalipah (2017) documents that in SSA, strong institutional environment impacts positively and significantly on the performance of microfinance institutions, which constitute an important engine of growth in the sub-region. Other recent studies, such as Malikane and Chitambara (2017), show that strong democratic institutions promote economic growth in Southern African economies.

In West Africa, Iheonu et al. (2017) investigated the impact of institutional quality on economic performance from 1996 to 2015 using a panel of 12 West African economies. The study used the traditional measures of institutional quality such as control of corruption, government effectiveness, regulatory quality and rule of law, and adopted fixed effect, random effect and panel two-stage least square models. The results overwhelmingly showed support for positive and significant impact of institutions on economic performance. Other studies that have shown that institutional quality is an important driver of growth in Africa, especially in West Africa include Ojapinwa (2017), Kebede and Takyi (2017), Amin (2013), and Kilishi et al. (2013).

In Nigeria, Dandume (2013) studied the relationship between institutions and growth performance using the ARDL approach. The findings indicate the existence of long run relationships between institutions and economic growth as well as a twoway causal relationship. Okoi, Okoi and Bassey (2015) also studied the relationship between institutional quality, macroeconomic policy, and economic development in Nigeria from 1995 to 2013, and found that contrary to Dandume (2013), the impact of domestic institution on Nigeria's development indices is insignificant. The findings of Okoi, Okoi and Bassey (2015) are however consistent with those of Iyoboyi and Pedro (2014), which also established that substantial amount of the changes in macroeconomic performance in Nigeria is not due to the quality of institutions. These conflicting findings in the extant literature for Nigeria means that a large scope still needs to be covered towards a more comprehensive understanding of the role of institutions in Nigeria.

Another recent study that has contributed towards a better understanding of the institutions-growth relationship in Nigeria is Olayungbo and Adediran (2017). This study investigated the effects of oil revenue and institutional quality on economic growth in Nigeria using annual data from 1984 to 2014 and the ARDL approach. Overall, the study established that institutional quality is important in explaining the relationship between oil revenue and economic growth in Nigeria. Akinkunmi (2017) also used the ARDL approach to establish that in the period 1960 to 2015 , political stability and political freedom have impact negatively but insignificantly on economic growth in Nigeria.

The foregoing overview of the literature indicates that the debate on the role of institutions in Nigeria's economic growth has just begun. However, it must be stressed the extant literature for Nigeria is yet to derive institutional quality variable from Freedom House database, which monitors political freedom in each country on an annual basis. For each country, the Freedom House institutional quality dummy variable takes the value of 2 for the classification free, 1 for partly free, and 0 for not free. We find that the dummy index ranged between 0 and 2 for Nigeria. Studies like Alexiou et al. (2014) have used the Freedom House institutional quality data with great success. This study will exploit the Freedom House dataset to 
investigate the role of institutional quality on economic performance in Nigeria.

\subsection{Theoretical Framework: \\ III METHODOLOGY}

The new growth theory indicates that growth of labour supply and growth of labour productivity are important factors in the economic growth process. Growth in labour productivity generally emanates from growth in human capital (i.e. accumulation of skills and knowledge), growth in investment (i.e. accumulation of physical capital), and technical progress (i.e. use of new and better production techniques). Following Tumwebaze and Ijjo (2015), we assume a Cobb-Douglas production function combining capital and labour with constant returns to scale so that aggregate output can be expressed as follows:

$$
Y=A K^{\alpha} L^{1-\alpha}
$$

where: $Y=$ real economic output, $A=$ technical progress, $K=$ capital (proxied in this study by gross fixed capital formation in constant local currency), and $L=$ labour (proxied by total adult population). The annual real GDP growth is obtained from equation (1) as:

$$
y=a+\alpha k+(1-\alpha) l
$$

where: $a, y, k$ and $l$ denote the growth rates of $A, Y$, $K$ and $L$, respectively. By assuming nondiminishing returns to the accumulation of both human capital and physical capital, the new growth theory is able to predict the long-term growth $P G D P_{t}=$ $f\left(P G D P_{t-1}, K_{t}, L_{t}, F D I_{t}, T R A D E_{t}, E X C H_{t}\right.$, $\left.I_{N S T}\right)$

where: $P G D P_{t}$ is real per capita GDP growth; $P G D P_{t-1}$ is the one lag of real per capita GDP growth; and $t$ represents the time index. Furthermore, equation (3) is expressed as an ARDL model in its unrestricted ECM form as follows: effects of institutional quality. Indeed, the extant literature has identified the channels through which institutional quality may impact on real per capita GDP growth. For instance, poor government regulations, lack of respect for the rule of law and civil liberties, lack of political rights and high level of corruption have been blamed for the economic stagnation in most developing countries, particularly the West African economies (Siba, 2008).

\subsection{Model Specification:}

To model the growth effect of institutional quality in Nigeria, we extend the economic growth function in (2) by including standard variables in growth regressions that are specific to the Nigerian economy, such as foreign direct investment inflow $\left(F D I_{t}\right)$, trade openness measured as (Exports + Imports)/GDP (\% of GDP) (TRADE $E_{t}$, nominal official exchange rate of local currency per U.S. dollar $\left(E X C H_{t}\right)$, and institutional quality $\left(I N S T_{t}\right)$. Even though these selected regressors are specific to the Nigerian economy, they are nonetheless consistent with some established studies in the literature such as Mankiw et al. (1992), Alexiou et al. (2014), and Tumwebaze and Ijjo (2015). The institutional quality variable used in this study is as defined in the last paragraph of Section 2. The entire data for this study is taken from the World Development Indicators published by the World Bank, except for the institutional quality variable, which was taken from Freedom House.

For the econometric analysis, we express the model for this study in its implicit form as follows: 


$$
\begin{aligned}
\triangle P G D P_{t}=\beta_{0} & +\beta_{1} P G D P_{t-1}+\beta_{2} K_{t-1} \\
& +\beta_{3} L_{t-1}+\beta_{4} F D I_{t-1} \\
& +\beta_{5} T R A D E_{t-1}+\beta_{6} E X C H_{t-1} \\
& +\beta_{7} I N S T_{t-1} \\
& +\sum_{i=1}^{p} \lambda_{i} \Delta P G D P_{t-i} \\
& +\sum_{i=0}^{q} \alpha_{i} \Delta K_{t-i}+\sum_{i=0}^{q} \gamma_{i} \Delta L_{t-i} \\
& +\sum_{i=0}^{q} m_{i} \Delta F D I_{t-i} \\
& +\sum_{i=0}^{q} \psi_{i} \Delta T R A D E_{t-i} \\
& +\sum_{i=0}^{q} \delta_{i} \Delta E X C H_{t-i} \\
& +\sum_{i=0}^{q} \phi_{i} \Delta I N S T_{t-i} \\
& +\varepsilon_{t} \ldots \ldots \ldots \ldots
\end{aligned}
$$

where: $\beta_{0}$ is the constant term; $\varepsilon_{t}$ is the stochastic error term; and all the variables are logged prior to estimation. In what follows, we provide some explanations on how each variable in equation (4) is expected to influence real per capita GDP growth.

In line with economic theory, the parameters of labour, capital, FDI and trade are expected to have positive signs since these variables are expected to engender growth, though some studies have established that FDI may not enhance growth sometimes (Iheonu, 2016). Some studies provide empirical support for expansionary effects of devaluations, but the contractionary effects have became more prominent in recent large number of studies, though mixed results and insignificant effect have also been reported by few studies (Razzaque et al., 2017). Thus, the parameter of exchange rate may be positive or negative. Some recent empirical studies in the literature have provided evidence suggesting a positive relationship between institutions that promote economic freedom and economic performance (Iheonu et al., 2017; Wanjuu and Le Roux, 2017); while other recent empirical studies have also documented that weak and poor institutional quality are growth retarding (Diop et al., 2010; Ajide and Raheem, 2016). Hence, the coefficient of institutional quality is expected to be either positive or negative.

\section{EMPIRICAL RESULTS AND DISCUSSION}

This empirical investigation began with a review of the descriptive statistics of the variables as shown in Table 1 . The variable names in Table 1 follow equation (4), except for the ones explained in the notes. We find from the mean, median, maximum and minimum values that the data shows the presence of no outliers. In addition, we find that the variables exhibit some variations exchange rate shows the highest level of variation while real GDP growth shows the least variation.

After the descriptive analysis, we examined the time series properties of the variables using the Phillips-Perron (PP) unit root test procedure. The results of this test are shown in Table 2. We find that all the variables are integrated of order one, indicating that they are not stationary at level. This suggests that a test for equilibrium relationship between the variables is important to guard against spurious regression. To do this, we adopted the bounds testing approach of Pesaran, Smith and Shin (2001, henceforth PSS). The results at both the aggregate and sectoral levels are shown in Table 3 . 
Table 1: Descriptive statistics of the variables

\begin{tabular}{lllllllllll}
\hline & AGRIC & CAPITAL & EXCH & FDI & IND & INST & LABOR & RGDP & SERV & TRADE \\
\hline Mean & 29.3830 & 28.9775 & 3.2840 & 21.1880 & 29.8917 & 0.8611 & 17.9500 & 12.3960 & 30.0134 & 3.8547 \\
Median & 29.1481 & 28.6692 & 3.9713 & 21.1718 & 29.7897 & 1.0000 & 17.9562 & 12.2639 & 29.7492 & 3.9773 \\
Maximum & 30.4566 & 30.0047 & 5.6431 & 22.9260 & 30.4542 & 2.0000 & 18.4190 & 12.8679 & 31.2393 & 4.4214 \\
Minimum & 28.4483 & 28.1788 & -0.5179 & 18.9107 & 29.3274 & 0.0000 & 17.4936 & 12.0479 & 29.1608 & 3.0137 \\
Std. Dev. & 0.6591 & 0.5963 & 1.9363 & 1.1006 & 0.3411 & 0.5369 & 0.2749 & 0.2673 & 0.6866 & 0.3812 \\
Skewness & 0.2554 & 0.5372 & -0.7297 & -0.1301 & 0.0878 & -0.1106 & -0.0117 & 0.5695 & 0.5572 & -0.6724 \\
Kurtosis & 1.5462 & 1.7091 & 2.1814 & 2.0934 & 1.6787 & 3.2050 & 1.7649 & 1.7174 & 1.8493 & 2.2967 \\
Observations & 144 & 144 & 144 & 144 & 144 & 144 & 144 & 144 & 144 & 144 \\
\hline
\end{tabular}

Source: Authors. Notes: The variable names are as defined in equation (4), except for AGRIC, IND and SERV which denote agric, industrial and services value added in constant local currency, respectively. All the variables reported are logged, except for INST.

Table 2: Phillips-Perron (PP) Unit Root Test Results

\begin{tabular}{|l|l|l|l|l|l|}
\hline Variable & PP Stat at Level & $\begin{array}{l}5 \% \\
\text { Value Critical }\end{array}$ & PP Stat at 1st Diff & $\begin{array}{l}5 \% \\
\text { Value }\end{array}$ & Critical \\
\hline rgdp & -2.259122 & -3.441552 & -5.359429 & -3.441777 & $\mathrm{I}(1)$ \\
\hline agric & -2.104674 & -3.441552 & -5.931677 & -3.441777 & $\mathrm{I}(1)$ \\
\hline ind & -3.181416 & -3.441552 & -5.222118 & -3.441777 & $\mathrm{I}(1)$ \\
\hline serv & -2.077678 & -3.441552 & -6.172591 & -3.441777 & $\mathrm{I}(1)$ \\
\hline capital & -3.139946 & -3.441552 & -5.601017 & -3.441777 & $\mathrm{I}(1)$ \\
\hline exch & -1.193364 & -3.441552 & -7.363059 & -3.441777 & $\mathrm{I}(1)$ \\
\hline fdi & -2.968485 & -3.441552 & -8.461000 & -3.441777 & $\mathrm{I}(1)$ \\
\hline labor & -2.802173 & -3.441552 & -4.234991 & -3.441777 & $\mathrm{I}(1)$ \\
\hline trade & -1.628731 & -3.441552 & -7.804269 & -3.441777 & $\mathrm{I}(1)$ \\
\hline
\end{tabular}

Source: Authors.

Table 3: PSS Bounds Test Results

\begin{tabular}{|l|l|l|l|l|}
\hline $\begin{array}{l}\text { Dependent } \\
\text { Variable }\end{array}$ & F-statistic & $\begin{array}{l}5 \% \text { Lower Bound } \\
\text { (I0 Bound) }\end{array}$ & $\begin{array}{l}\text { 5\% Upper Bound } \\
\text { (I1 Bound) }\end{array}$ & Decision \\
\hline Rgdp & 4.375912 & 2.45 & 3.61 & Cointegration \\
\hline Agric & 5.095552 & 2.45 & 3.61 & Cointegration \\
\hline Ind & 3.731531 & 2.45 & 3.61 & Cointegration \\
\hline Serv & 6.583003 & 2.45 & 3.61 & Cointegration \\
\hline
\end{tabular}

Source: Authors

The results in Table 3 indicate that a stable long-run relationship exists among the variables regardless of whether the aggregate log real GDP or the log sectoral value added is the dependent variable. This means that in all cases, the null hypothesis of no cointegration is rejected. The ARDL model for the aggregate output, using the real GDP growth as dependent variable, is reported in Table 4.
The results in Table 4 indicate that the long-run parameter for INST is given by $-(0.38725) / 1.40757$ $=-0.27512$. However, the p-value of 0.0758 shows that this parameter is not statistically significant at the conventional 5\% level. Table 4 also shows that in the short-run, INST impacts negatively on real GDP growth with a p-value of 0.9332 , which is not statistically significant at the $5 \%$ level. Overall, we 
find that the institutional quality variable impacts negatively but insignificantly on growth in Nigeria, both in the short-run and long-run. These findings are consistent with Okoi, Okoi and Bassey (2015) and Iyoboyi and Pedro (2014), which also found that the quality of institutions in Nigeria has not impacted significantly on macroeconomic performance. The findings are also consistent with Diop et al. (2010) and Ajide and Raheem (2016), which have also documented that weak and poor institutional quality is growth retarding. Indeed, these results are not surprising given that the Nigerian economy has been bedeviled by several issues relating to poor institutional quality such as endemic corruption, poor regulations, disregard for the rule of law, long years of military dictatorship/political instability, and so on.

Table 4 further shows that both in the long-run and short-run, the initial level of per capita income is an important driver of growth in Nigeria. This is consistent with the bulk of the extant literature such as Iheonu et al. (2017) and Levine and Renelt (1992). While Iheonu et al. (2017) established that initial per capita income is an important driver of growth in West Africa, Levine and Renelt (1992) found that the initial level of real GDP per capita is an important driver of GDP per capita growth in a group of 101 countries. Other significant drivers of growth in the short-run are capital and labor, while trade is growth retarding.

To check if the foregoing results are robust to sectoral output growth in Nigeria, we estimated equation (4) separately using agric, industrial and services sectoral output growth as the dependent variables, respectively. The results are reported in the Appendix. Here, Panel 1 reports for the agric output growth equation, while Panels 2 and 3 report for industrial and services sectoral output growth equations, respectively. We find that even at the sectoral level, the role of institutional quality on output growth in Nigeria remained muted in the long-run throughout, except in the case of the industrial sector where it is significant at the 5\% level. We also find that in the short-run, the impact of institutional quality on sectoral output growth remained unimportant all through. In fact, our results indicate that the impact of this variable is negative in all cases in the short-run, except for the services sector in which the impact is positive. Overall, we find that both at aggregate and sectoral levels, the impact of institutional quality on output growth is overwhelmingly negative but negligible.

Table 4: ARDL Estimation Results for Aggregate Output (Dependent Variable D(RGDP))

\begin{tabular}{|l|l|l|l|l|}
\hline Variable & Coefficient & Std. Error & t-Statistic & Prob. \\
\hline D(RGDP(-1) & 0.44400 & 0.07353 & 6.0383 & 0.0000 \\
\hline D(RGDP(-2) & 0.17972 & 0.07741 & 2.3216 & 0.0220 \\
\hline D(CAPITAL(-1)) & 0.05516 & 0.02327 & 2.3708 & 0.0194 \\
\hline D(EXCH) & -0.00682 & 0.00417 & -1.6367 & 0.1044 \\
\hline D(FDI) & -0.00404 & 0.00653 & -0.6188 & 0.5373 \\
\hline D(LABOR) & 0.07754 & 0.03522 & 2.2014 & 0.0297 \\
\hline D(TRADE) & -0.06152 & 0.01590 & -3.8679 & 0.0002 \\
\hline D(INST(-1)) & -0.00056 & 0.00660 & -0.0840 & 0.9332 \\
\hline RGDP(-1) & 1.40757 & 0.07555 & 18.6321 & 0.0000 \\
\hline CAPITAL(-1) & -0.54870 & 0.44717 & -1.2271 & 0.2223 \\
\hline EXCH(-1) & -0.18721 & 0.12184 & -1.5366 & 0.1272 \\
\hline FDI(-1) & 0.25865 & 0.12931 & 2.0002 & 0.0479 \\
\hline LABOR(-1) & 2.12847 & 1.17799 & 1.8069 & 0.0734 \\
\hline TRADE(-1) & -0.23566 & 0.16128 & -1.4612 & 0.1467 \\
\hline INST(-1) & 0.38725 & 0.21610 & 1.7919 & 0.0758 \\
\hline Constant & -14.18246 & 12.82493 & -1.1059 & 0.2711 \\
\hline Diagnostics & & & & \\
\hline R-squared & 0.998322 & & F-statistic & 2826.729 \\
\hline Adjusted R-squared & 0.997969 & & Prob(F-statistic) & 0.0000 \\
\hline & & & \\
\hline
\end{tabular}




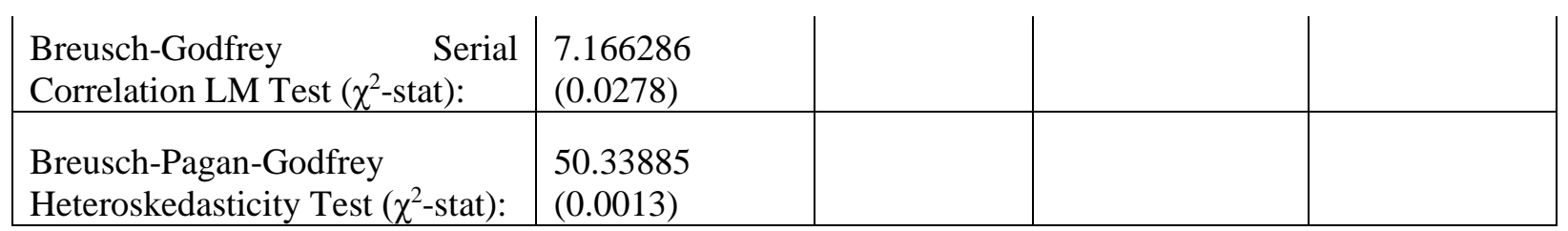

Source: Authors. Notes: Standard errors are Newey-West HAC standard errors. P-values are in parenthesis.

In the short-run, the results indicate that important drivers of growth include the initial level of output growth, capital (in the case of agric and services sectors) and labour (in the case of agric and industrial sectors), while trade is growth retarding all through. However, in the long-run, only labour exerts significant influence on output growth. These results substantially reflect the structure and dynamics of the Nigerian economy. For instance, the finding that trade is detrimental to growth in Nigeria is consistent with recent empirical evidence such as Iheonu et al. (2017) and Keho (2017), and this may be due to low trade volumes and negative trade balances recorded in Nigeria in the last two decades as well as the structural defects that characterize the economy such as poor transport infrastructure that hinders trade. Furthermore, the unimportant role of trade may also be explained by the fact that bilateral trade between Nigeria is more in terms of trade diversion than trade creation resulting from economic distortions that encourage illegal trade, which in turn significantly reduce bilateral trade between Nigeria and the rest of the world (Agbodji, 2008).

In terms of diagnostics, our results indicate the presence of the problems of autocorrelation and heteroskedasticity only in the aggregate equation reported in Table 4. However, we corrected for these problems using the Newey-West Heteroskedasticity and Autocorrelation Corrected (HAC) standard errors in order to restore the validity of the model. Besides, the ARDL approach adopted in this study corrects for any potential problem of weak endogeneity that usually bedevil growth equations through its lag structure. The F-Statistics indicate that all the models are statistically significant even at the $1 \%$ level.

\section{CONCLUSION AND POLICY RECOMMENDATIONS}

The question of whether institutional quality is an important driver of growth has been the subject of a growing literature in both developed and developing economies across the globe. This study revisits this relationship in Nigeria from 1981Q1 to 2016Q4. However, unlike the extant literature which derived institutional quality variables from the World Governance Indicators, this study built the institutional quality data from Freedom House database, which monitors political freedom across the globe. The study adopted the ARDL approach to modeling levels relationships recently advanced by Pesaran, Smith and Shin (2001). Overall, we find that the institutional quality variable impacts negatively but insignificantly on growth in Nigeria, both at the aggregate and sectoral levels. These results are robust both in the short-run and long-run. However, our results further indicate that initial output growth levels, capital and labour are important drivers of growth in Nigeria, while trade is growth-retarding.

The findings of this study have several policy implications. In this post Covid-19 era, policymakers in Nigeria are able to see that there is need to improve the quality of socio-economic and political institutions in the country so that a more robust impact of these institutions can be felt in the economic performance of the country. Specifically, the proposed improvements should target such areas as control of corruption, government effectiveness, regulatory quality, political stability, and respect for the rule of law and accountability. This means that policy reforms should be evolved to enhance these institutional frameworks in the country. Such reforms should be coordinated and escalated at all levels of government. From the findings of this study, policymakers in Nigeria are also able to see that higher levels of capital accumulation and human capital development are important for sustainable growth and development in the country. Thus, policy reforms in the country during this post Covid19 period should support improved socio-political and economic environment that can attract higher levels of investment and enhance the quality of the labour force. This requires extensive structural transformations in order to make the economic environment more attractive to prospective investors. The proposed structural transformations can be achieved through the removal of bottlenecks to private and public investments, increased investment in basic infrastructure to drive productivity, increased government support to micro, small and medium scale enterprises, removal 
of bottlenecks to transfer of land ownership and transparency in the enforcement of property rights. These will help Nigeria to maintain quality institutions that can attract more investments, increase trade and promote sustained economic growth and development even in this post Covid-19 era.

\section{References}

[1] Agbodji, A. E. (2008). The Impact of Subregional Integration on Bilateral Trade: The Case of UEMOA. African Economic Research Consortium (AERC) Research Paper, No. 186, Nairobi.

[2] Ajide, K.B. and Raheem, I.D. (2016). The Institutional Quality Impact on Remittances in the ECOWAS Sub-Region. African Development Review, 28(4), 462-481.

[3] Akinkunmi, M.A. (2017). Nigeria's Economic Growth: Past, Present and Determinants. Journal of Economics and Development Studies, 5(2), 31 - 46.

[4] Alexiou, C., Tsaliki, P. and Osman, H. R. (2014). Institutional quality and economic growth: empirical evidence from the Sudanese economy. Economic Annals, LIX(203), 119 - 137.

[5] Amin, A. A. (2013). Africa's Development: Institutions, Economic Reforms and Growth. International Journal of Economics and Financial Issues, 3(2), 324-336.

[6] Anyanwu, J. C. (2014). Factors Affecting Economic Growth in Africa: Are There any Lessons from China? African Development Review, 26(3), $468-493$.

[7] Anyanwu, J.C. and Yaméogo, N.D. (2015). Regional Comparison of Foreign Direct Investment to Africa: Empirical Analysis. African Development Review, 27(4), 345-363.

[8] Benyah, F. E. K. (2010). Determinants of financial development: A focus on African countries. Master Degree thesis, Jonkoping University. Retrieved 15 June 2018 from http://hj.divaportal.org/smash/get/diva2:337616/FULLTEXT01.
[9] Chikalipah, S. (2017). Institutional Environment and Microfinance Performance in Sub-Saharan Africa. African Development Review, 29(1), 16-27.

[10] Dandume, M.Y. (2013). Institution and Economic Growth performance in Nigeria. MPRA Paper No. 52356. Retrieved from https://mpra.ub.unimuenchen.de/52356/1/MPRA_paper_52356.pdf (Accessed: 10th May, 2019).

[11] Diop, A., Dufrenot, G. and Sanon, G. (2010). Is Per Capita Growth in Africa Hampered by Poor Governance and Weak Institutions? An Empirical Study on the ECOWAS Countries. African Development Review, 22(2), 265-75.

[12] Iheonu, C.O. (2016). Does FDI Crowd out or Crowd in Domestic Investment? Evidence from

Sub Saharan Africa. Africa Journal of Social Sciences, 6(1), 69-77.

[13] Iheonu, C., Ihedimma, G. and Onwuanaku, C. (2017). Institutional Quality and Economic

Performance in West Africa. MPRA Paper No. 82212. Retrieved 15 June 2018 from: https://mpra.ub.uni-muenchen.de/82212/

[14] Iyoboyi, M. and Pedro, L. M. (2014). Institutional capacity and macroeconomic performance: empirical evidence from Nigeria. Research in Applied Economics, 6(1), 38-60.

[15] Kebede, J. G. and Takyi, P. O. (2017). Causality between institutional quality and economic growth: Evidence from Sub-Saharan Africa. European Journal of Economic and Financial Research, 2(1), 114 - 131.

[16] Keho, Y. (2017). The impact of trade openness on economic growth: The case of Cote d'Ivoire. Cogent Economics \& Finance, 5(1), 1 - 14.

[17] Kilishi, A. A., Mobolaji, H. I., Yaru, M. A. and Yakubu, A. T. (2013). Institutions and Economic Performance in Sub-Saharan Africa: A Dynamic Panel Data Analysis. Journal of African Development, 15(2), 91 - 120.

[18] Knack, S. and Keefer, P. (1995). Institutions and Economic Performance: Cross-country Tests Using Alternative Institutional Measures. Economics and Politics, 7(3), 207-228. 
[19] Levine, R. and Renelt, D. (1992). A sensitivity analysis of cross-country growth regressions. The American Economic Review, 82(4), 942 - 963.

[20] Malikane, C. and Chitambara, P. (2017). Foreign Direct Investment, Democracy and Economic Growth in Southern Africa. African Development Review, 29(1), 92-102.

[21] Mankiw, N. G., Romer, D. and Weil, D. N. (1992). A contribution to the empirics of economic growth. Quarterly Journal of Economics, 107(2), $407-437$.

[22] Mauro, P. (1995). Corruption and Growth. The Quarterly Journal of Economics, 110(3), 681-712.

[23] Mijiyawa, A. G. (2013). Africa's Recent Economic Growth: What Are the Contributing Factors? African Development Review, 25(3), 289 302.

[24] Mijiyawa, A. G. (2015). What Drives Foreign Direct Investment in Africa? An Empirical Investigation with Panel Data. African Development Review, 27(4), 392-402.

[25] North, D.C. (1991). Institutions. Journal of Economic Perspectives, 5(1), 97-112.

[26] Ojapinwa, T. V. (2017). Remittances, Institutional Quality and Economic Growth in SubSaharan Africa. AEC Manuscript, Department of Economic, University of Lagos, Nigeria.

[27] Okoi, I.E., Okoi, O.B. and Bassey, C.E. (2015). Institutional Quality, Macroeconomic Policy and Economic Development in Nigeria. Journal of Economics and Development Studies, 3(2), 140 145.

[28] Olayungbo, O.D and Adediran, K.A. (2017). Effects of Oil Revenue and Institutional Quality on
Economic Growth with an ARDL Approach. Energy and Policy Research, 4(1), 44-54.

[29] Pesaran, M.H., Smith, R.J. and Y. Shin (2001). Bounds Testing Approaches to the Analysis of Level Relationships. Journal of Applied Econometrics 16, 289-326.

[30] Razzaque, M. A., Bidisha, S. H. and Khondker, B. H. (2017). Exchange rate and economic growth: An empirical assessment for Bangladesh. Journal of South Asian Development, 12(1), 42 - 64.

[31] Siba E.G. (2008). Determinants of institutional quality in Sub-Saharan African countries. Working Papers in Economics No 310, School of Business Economics and Law, University of Gothenburg.

[32] Tumwebaze, H. K. and Ijjo, A. T. (2015). Regional economic integration and economic growth in the COMESA region, $1980-2010$. African Development Review, 27(1), 67 - 77.

[33] Wanjuu, L. and Le Roux, P. (2017). Economic institutions and economic growth: Empirical evidence from the Economic Community of West African States. South African Journal of Economic and Management Sciences, 20(1), $1-10$.

\section{Creative Commons Attribution License 4.0 (Attribution 4.0 International, CC BY 4.0)}

This article is published under the terms of the Creative Commons Attribution License 4.0 https://creativecommons.org/licenses/by/4.0/deed.en_US 


\section{Appendix}

Figure 1: GDP Growth Performance of Nigeria (2008 to 2017)

Panel A: GDP Growth (Annual \%)

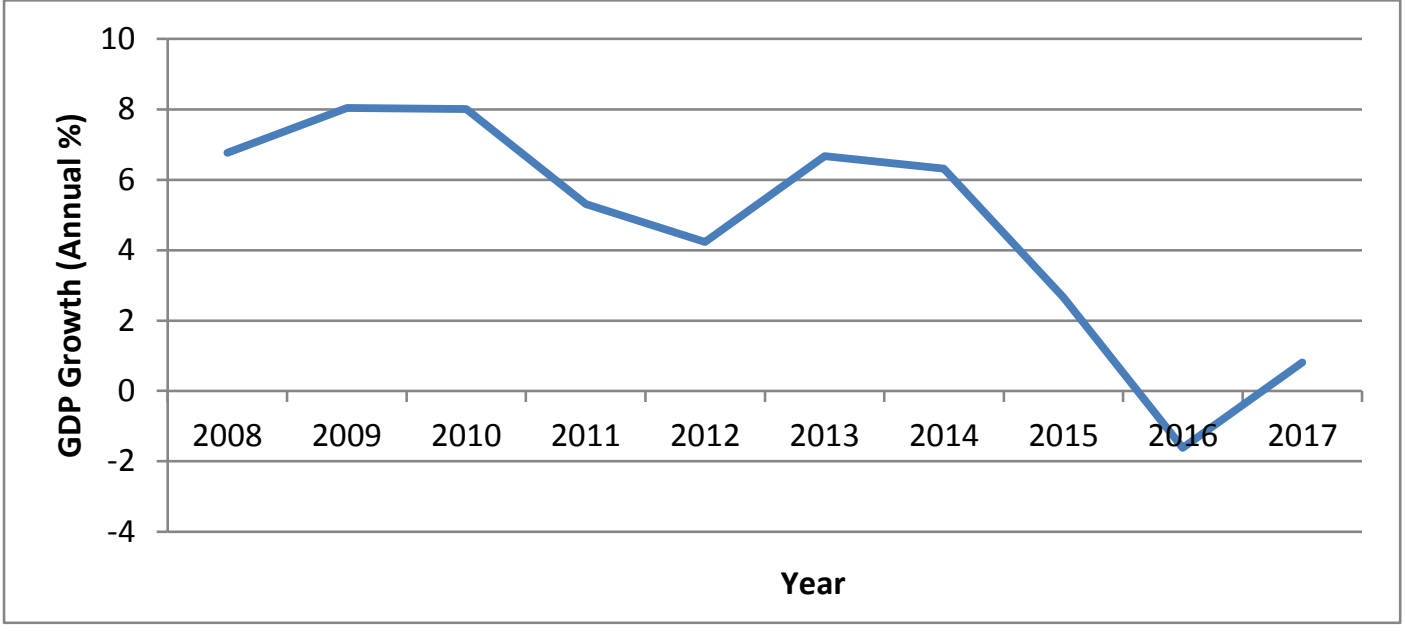

Panel B: GDP Per Capita Growth (Annual \%)

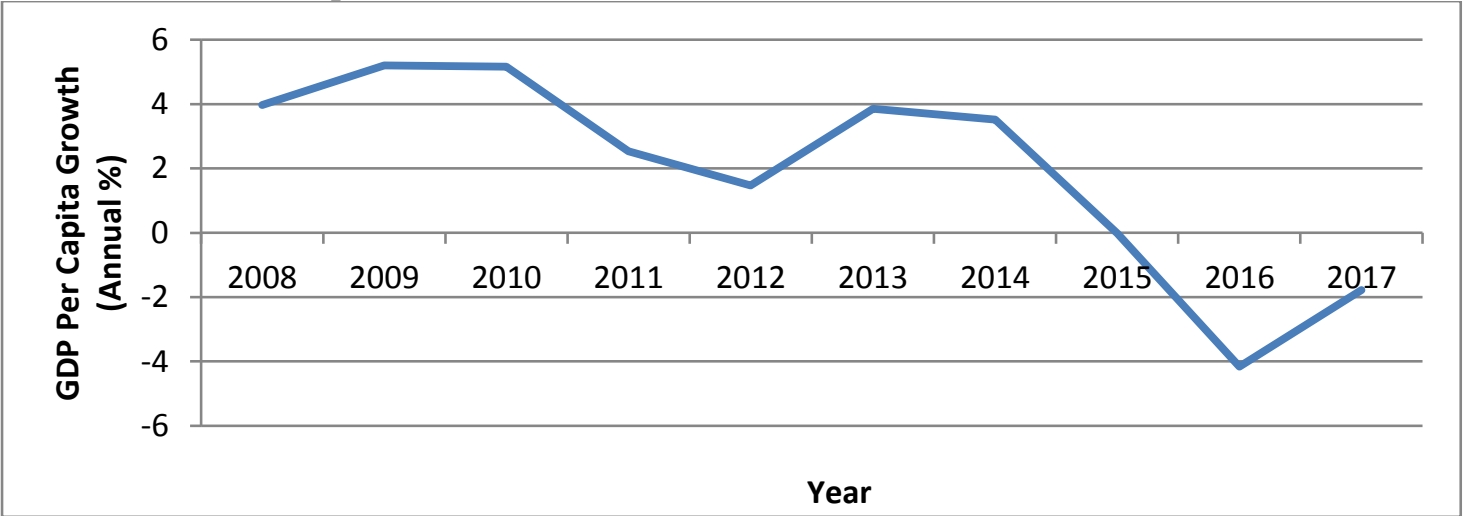

Source: Authors, with data from World Development Indicators

Panel 1: ARDL Estimation Results for Aggregate Output (Dependent Variable D(AGRIC))

\begin{tabular}{|l|l|l|l|l|}
\hline Variable & Coefficient & Std. Error & t-Statistic & Prob. \\
\hline $\mathrm{D}($ AGRIC(-1)) & 0.55029 & 0.07394 & 7.4421 & 0.0000 \\
\hline $\mathrm{D}($ CAPITAL(-1)) & 0.14886 & 0.05749 & 2.5893 & 0.0110 \\
\hline $\mathrm{D}(\mathrm{EXCH})$ & 0.00059 & 0.00588 & 0.1006 & 0.9200 \\
\hline $\mathrm{D}($ FDI $)$ & 0.00424 & 0.00490 & 0.8648 & 0.3891 \\
\hline $\mathrm{D}($ LABOR(-1)) & 19.79196 & 6.46971 & 3.0592 & 0.0028 \\
\hline $\mathrm{D}($ TRADE $)$ & -0.18925 & 0.03079 & -6.1464 & 0.0000 \\
\hline $\mathrm{D}($ INST(-1) & -0.00818 & 0.00956 & -0.8554 & 0.3943 \\
\hline AGRIC(-1) & 1.50188 & 0.07535 & 19.9330 & 0.0000 \\
\hline
\end{tabular}




\begin{tabular}{|l|l|l|l|l|} 
CAPITAL(-1) & -0.37827 & 0.25107 & -1.5067 & 0.1349 \\
\hline EXCH(-1) & 0.01221 & 0.12133 & 0.1007 & 0.9200 \\
\hline FDI(-1) & 0.08758 & 0.08489 & 1.0316 & 0.3046 \\
\hline LABOR(-1) & 2.68329 & 1.02219 & 2.6251 & 0.0099 \\
\hline TRADE(-1) & -0.39392 & 0.18724 & -2.1038 & 0.0378 \\
\hline INST(-1) & 0.10571 & 0.10186 & 1.0377 & 0.3017 \\
\hline CONSTANT & -6.70513 & 13.58068 & -0.4937 & 0.6225 \\
\hline Diagnostics & & & & \\
\hline R-squared & 0.999434 & & F-statistic & 6042.534 \\
\hline Adjusted R-squared & 0.999269 & & Prob(F-statistic) & 0.0000 \\
\hline $\begin{array}{l}\text { Breusch-Godfrey Serial Correlation } \\
\text { LM Test } \chi^{2} \text {-stat): }\end{array}$ & 3.020856 & & & \\
\hline $\begin{array}{l}\text { Breusch-Pagan-Godfrey } \\
\text { Heteroskedasticity Test }\left(\chi^{2} \text {-stat): }\right.\end{array}$ & $\begin{array}{l}0.2208) \\
\text { Source: Als }\end{array}$ & & & \\
\hline
\end{tabular}

Source: Authors. Notes: P-values are in parenthesis.

Panel 2: ARDL Estimation Results for Aggregate Output (Dependent Variable D(IND))

\begin{tabular}{|c|c|c|c|c|}
\hline Variable & Coefficient & Std. Error & t-Statistic & Prob. \\
\hline $\mathrm{D}(\mathrm{IND}(-1))$ & 0.78404 & 0.07380 & 10.6244 & 0.0000 \\
\hline $\mathrm{D}(\mathrm{IND}(-2))$ & 0.16935 & 0.07784 & 2.1757 & 0.0320 \\
\hline D(CAPITAL) & 0.02324 & 0.02318 & 1.0025 & 0.3186 \\
\hline $\mathrm{D}(\mathrm{EXCH})$ & -0.00065 & 0.00383 & -0.1708 & 0.8647 \\
\hline $\mathrm{D}(\mathrm{FDI})$ & -0.00437 & 0.00628 & -0.6959 & 0.4881 \\
\hline $\mathrm{D}(\mathrm{LABOR})$ & 20.88977 & 4.41877 & 4.7275 & 0.0000 \\
\hline $\mathrm{D}(\mathrm{TRADE}(-1))$ & -0.10723 & 0.02764 & -3.8789 & 0.0002 \\
\hline $\mathrm{D}(\mathrm{INST})$ & -0.00854 & 0.00486 & -1.7561 & 0.0822 \\
\hline $\operatorname{IND}(-1)$ & 1.70830 & 0.07860 & 21.7343 & 0.0000 \\
\hline CAPITAL(-1) & -0.05948 & 0.09017 & -0.6596 & 0.5110 \\
\hline $\mathrm{EXCH}(-1)$ & -0.00863 & 0.05049 & -0.1709 & 0.8647 \\
\hline FDI(-1) & 0.06283 & 0.03550 & 1.7699 & 0.0798 \\
\hline LABOR(-1) & 1.12545 & 0.40547 & 2.7756 & 0.0066 \\
\hline TRADE(-1) & 0.04023 & 0.07939 & 0.5068 & 0.6134 \\
\hline INST(-1) & 0.10437 & 0.04480 & 2.3298 & 0.0218 \\
\hline CONSTANT & 9.84346 & 5.70840 & 1.7244 & 0.0878 \\
\hline \multicolumn{5}{|l|}{ Diagnostics } \\
\hline R-squared & 0.999234 & & F-statistic & 3488.971 \\
\hline Adjusted R-squared & 0.998947 & & Prob(F-statistic) & 0.0000 \\
\hline $\begin{array}{l}\text { Breusch-Godfrey Serial } \\
\text { Correlation LM Test }\left(\chi^{2} \text {-stat): }\right.\end{array}$ & $\begin{array}{l}2.949137 \\
(0.2289) \\
\end{array}$ & & & \\
\hline $\begin{array}{l}\text { Breusch-Pagan-Godfrey } \\
\text { Heteroskedasticity Test }\left(\chi^{2} \text {-stat): }\right.\end{array}$ & $\begin{array}{l}30.13595 \\
(0.6105) \\
\end{array}$ & & & \\
\hline
\end{tabular}

Source: Authors. Notes: P-values are in parenthesis. 
Panel 3: ARDL Estimation Results for Aggregate Output (Dependent Variable D(SERV))

\begin{tabular}{|c|c|c|c|c|}
\hline Variable & Coefficient & Std. Error & t-Statistic & Prob. \\
\hline $\mathrm{D}(\operatorname{SERV}(-1))$ & 0.60944 & 0.07219 & 8.4420 & 0.0000 \\
\hline D(CAPITAL $(-1))$ & 0.05296 & 0.01932 & 2.7413 & 0.0070 \\
\hline $\mathrm{D}(\mathrm{EXCH})$ & 0.00156 & 0.00344 & 0.4528 & 0.6515 \\
\hline $\mathrm{D}(\mathrm{FDI}(-1))$ & -0.01161 & 0.00605 & -1.9198 & 0.0572 \\
\hline $\mathrm{D}(\mathrm{LABOR})$ & 5.88256 & 3.58740 & 1.6398 & 0.1036 \\
\hline D(TRADE) & -0.09100 & 0.01490 & -6.1069 & 0.0000 \\
\hline $\mathrm{D}(\mathrm{INST})$ & 0.00864 & 0.00466 & 1.8563 & 0.0658 \\
\hline SERV $(-1)$ & 1.60205 & 0.06946 & 23.0654 & 0.0000 \\
\hline CAPITAL(-1) & -0.85344 & 2.39159 & -0.3568 & 0.7218 \\
\hline $\mathrm{EXCH}(-1)$ & 0.21061 & 0.71074 & 0.2963 & 0.7675 \\
\hline FDI $(-1)$ & 0.01405 & 0.00609 & 2.3082 & 0.0226 \\
\hline LABOR(-1) & 8.79336 & 3.54144 & 2.4830 & 0.0144 \\
\hline TRADE(-1) & -0.65118 & 1.15583 & -0.5634 & 0.5742 \\
\hline INST(-1) & 0.00864 & 0.00466 & 1.8563 & 0.0658 \\
\hline CONSTANT & 25.74360 & 99.68120 & 0.2583 & 0.7966 \\
\hline \multicolumn{5}{|l|}{ Diagnostics } \\
\hline R-squared & 0.999763 & & F-statistic & 30808.86 \\
\hline Adjusted R-squared & 0.999731 & & Prob(F-statistic) & 0.0000 \\
\hline $\begin{array}{l}\text { Breusch-Godfrey Serial } \\
\text { Correlation LM Test }\left(\chi^{2} \text {-stat): }\right.\end{array}$ & $\begin{array}{l}2.948381 \\
(0.229)\end{array}$ & & & \\
\hline $\begin{array}{l}\text { Breusch-Pagan-Godfrey } \\
\text { Heteroskedasticity Test }\left(\chi^{2} \text {-stat): }\right.\end{array}$ & $\begin{array}{l}19.67419 \\
(0.2353)\end{array}$ & & & \\
\hline
\end{tabular}

Source: Authors. Notes: P-values are in parenthesis. 